\title{
Property law as a barrier to energy upgrades in multi-owned properties: insights from a study of England and Scotland
}

\author{
David Weatherall • Frankie McCarthy • Susan Bright
}

Received: 28 October 2016 / Accepted: 15 May 2017 / Published online: 1 August 2017

(C) The Author(s) 2017. This article is an open access publication

\begin{abstract}
Is the law of ownership a barrier to energy upgrades in apartment blocks? Co-owners in multiowned properties face challenges in reaching agreement to implement energy efficiency measures that owners of single family residences do not encounter. At the European level, this difficulty is recognised in Article 19 of the 2012 Energy Efficiency Directive, by which governments are obliged to address barriers to improvements which arise in the specific context of multi-owner properties. Despite this, the position of apartment owners remains mostly invisible in the policy discourse. The small quantity of literature examining the difficulties of group decision making around energy efficiency in apartments has so far focused on mapping the issues. This paper begins the process of 'colouring in' the existing outlines by providing an indepth delineation of the governance barriers to energy upgrades presented by the law of ownership and
\end{abstract}

This paper arises from the University of Oxford's HEIF allocation.

D. Weatherall $(\square)$

Future Climate, London and University of Oxford, Oxford, UK e-mail: david@futureclimate.org.uk

URL: http://www.oxford.ac.uk/law/futureproofingflats ?

F. McCarthy

School of Law, University of Glasgow, Glasgow, UK

e-mail: frankie.mccarthy@glasgow.ac.uk

URL: http://www.gla.ac.uk/schools/law/staff/frankiemccarthy

\section{S. Bright}

New College, University of Oxford, Oxford, UK

e-mail: Susan.bright@law.ox.ac.uk

URL: https://www.law.ox.ac.uk/people/susan-bright management in two European jurisdictions: England and Scotland. A doctrinal analysis is employed to ascertain the relevant legal issues and identify how property law constitutes a barrier to energy upgrades within the framework of existing behavioural models. A theoretical inquiry is then used to suggest that reconceptualising property law in the context of multi-owner properties to focus on collective responsibilities rather than individual rights may help to minimise this effect of the law. The paper concludes with recommendations for further research to identify the range of issues property law presents across EU member states. This data is needed to fully test the reconceptualisation hypothesis presented here.

Keywords End-use energy efficiency · Decision making $\cdot$ Buildings $\cdot$ Law $\cdot$ Scotland $\cdot$ England

\section{Introduction}

To achieve its target of 20\% energy savings by 2020 , the European Union has major ambitions for the refurbishment of existing housing stock, set out most notably in the 2010 recast Energy Performance of Buildings Directive $^{1}$ and the 2012 Energy Efficiency Directive (EED). ${ }^{2}$ Forty percent of European dwellings are

\footnotetext{
${ }^{1}$ Directive 2010/31/EU of The European Parliament and of The Council of 19 May 2010 on the energy performance of buildings (recast).

${ }^{2}$ Directive 2012/27/EU of The European Parliament and of The Council of 25 October 2012 on energy efficiency.
} 
multi-owned properties (MoPs) (Bright and Weatherall 2017) - known variously as apartments, condominiums and multifamily buildings amongst other terms - and the majority of the European housing stock is privately owned (Eurostat 2015). Accordingly, retrofitting of MoPs must form a key aspect of energy efficiency strategy for governments throughout the EU. Studies show, however, that MoPs, whether purpose built or converted from other buildings, are in many countries less likely to undergo major refurbishment than single family houses (Low Energy Apartment Futures (LEAF) 2016). The barriers to energy upgrades that apply in all types of home (such as the need for upfront financing) are compounded for MoPs by the complexity of the way that MoPs are owned and management decisions are taken. Further, within the EU, each country has different national laws about how MoPs are owned and managed. The dimension of 'owning part within a whole' raises important practical and theoretical issues about the nature of ownership and responsibility to others.

The EED recognises that multi-owned and multioccupied buildings face particular challenges in relation to energy efficiency upgrades. Article 19 requires governments to address barriers to improvements in MoPs which relate to the fact that there may not be rules for cost sharing, individuals may not obtain full benefits from the improvement, or decision-making processes may need better regulation. Despite this recognition, Matschoss et al. (2013, p. 1493) suggest that the particular problems of MoPs are not 'very visible in the policy discourse' targeting buildings and the environment, which tends to focus 'on barriers to energy investment at a relatively generic level'.

This paper focuses on the specific barriers to energy upgrades in apartments created by the law regulating ownership and management of MoPs. By energy upgrades, ${ }^{3}$ we refer to installations of energy efficiency improvements to building fabric (insulation or improved windows); installation or upgrades to deliver more efficient, lower carbon and renewable energy heating systems; energy efficiency upgrades to other fixed energyusing systems in the building (lighting, ventilation and elevators); installation of renewable electricity generation (principally solar photovoltaics (PV)); and installation of smart metering or other building energy

\footnotetext{
${ }^{3}$ We intentionally use, as a general term, 'energy upgrades' rather than 'energy improvements' as the contested interpretation of the term 'improvement' in property law is one of the main themes of the paper.
}

management system. Depending on the measure and the building concerned, these measures may be installed within (or to the sole benefit of) individual apartments or across the whole building.

The first part of the paper contains a review of literature on barriers to energy efficiency in this context, summarising the relevant barriers that have been recognised by earlier studies. 'Methodology' then sets out the methodological approaches employed in the remainder of the paper, namely a doctrinal analysis followed by a theoretical inquiry. In 'Governance arrangements in England' and 'Governance arrangements in Scotland', doctrinal analysis is employed to ascertain the law concerning ownership and management of MoPs in two European jurisdictions with very distinct legal systems: England and Scotland. 'How property law acts as a barrier to energy upgrades in MoPS' relies on these doctrinal findings to identify how property law constitutes a barrier to energy upgrades within the framework of existing behavioural models. In 'Reconceptualising property law in MoPS to minimise governance barriers', a theoretical inquiry drawing on 'progressive property' scholarship is used to develop the argument that property law should be reconceptualised in the context of MoPs to focus on the collective responsibilities shared by every person with a legal interest in the building rather than on the rights held by individual apartment owners. The hypothesis is presented that this ground-level reconceptualisation would serve to minimise the role of property law as a barrier to energy upgrades in MoPs. The paper concludes with recommendations for further research to identify the range of issues property law presents across EU member states. This data is needed to fully test the reconceptualisation hypothesis suggested in 'Reconceptualising property law in MoPS to minimise governance barriers'.

\section{Existing literature on barriers to energy efficiency}

This paper situates itself within the broader literature on the 'energy efficiency gap' (Hirst and Brown 1990) that exists between actual energy use and optimal levels of energy efficiency variously defined (Jaffe and Stavins 1994). Since this gap was first identified, researchers across a range of disciplines have used barrier models to explain its existence. Weber (1997, p. 834) identifies a barrier model in this context as encapsulating three features - the objective obstacle, the subject hindered 
and the action hindered - and describes the methodological question of how to determine a barrier model as 'what is an obstacle to whom reaching what in energy conservation?'.

A dominant policy and research model for understanding energy use is 'PTEM' - a physical, technical and economic model which adopts an engineeringcentric approach to energy efficiency which in turn is affected by economics (Lutzenhiser 1993; Janda et al. 2015). Within this model, human behaviour is implicitly assumed to be economically rational. In the context of MoPs, however, human behaviour is importantly mediated by property law and ownership arrangements, which will affect how decisions are taken and the way in which economic factors play out. Hirst and Brown's (1990) original work recognised the importance of barriers to rational decision making for energy efficiencyboth structural barriers (including limited access to capital, government fiscal and regulatory policies, codes and standards) and behavioural barriers (including attitudes towards energy efficiency, perceived risk of energy-efficiency investments, information gaps and misplaced incentives). Sorrell et al. (2000, p. 12) classify barriers that limit the installation of technologies that are energy efficient and economically efficient, stating that these can be understood from 'economic', 'behavioural' or 'organisational' perspectives. The legal and governance arrangements explored in this paper constitute particular barriers to energy efficiency that have been neglected by the energy literature but can be understood within all of these perspectives. Thus, property law and ownership arrangements prevalent in MoPs cause and exacerbate problems of poorly defined property rights and asymmetric information, leading to market failure within the perspectives of 'structural' and 'economic' barriers identified by Hirst and Brown (1990) and Sorrell (2000). Adopting Sorrell's (2000) organisational perspective, the co-owners of a MoP can be understood as an organisation within which power relations may inhibit action on energy upgrades. Finally, behavioural barriers (identified by Sorrell 2000 and Hirst and Brown 1990) may include routines, practices and attitudes adopted by individuals or groups in managing MoPs which inhibit energy efficiency investments.

Other theoretical positions question the value of analysing and categorising barriers to energy efficiency. These authors argue such an approach has failed to close the 'energy efficiency gap' over the past 40 years or so
(Janda et al. 2015, p. 3; Shove 2010, p. 1274). Although we are cognisant of these criticisms, we use the language of barriers in particular because this has been adopted as a language by energy efficiency policy makers (for example in the EED). The focus of our research is on 'drilling down' into the detail of the property law in relation to energy upgrades in MoPs, rather than on developing an overall —or paradigm - framework.

A literature focusing on the particular barriers that arise in relation to refurbishment of MoPs has begun to emerge only recently. Important work carried out by Matschoss et al. (2013) identified the collective decision-making processes required of owners and other interested parties in MoPs as a key obstacle that did not easily find an equivalent in other contexts. This finding is backed up by a 2014 survey of energy efficiency policy makers from 21 countries for the Concerted Action on the EED, in which 12 countries stated that decision making between owners in residential buildings was 'often' or 'always' a barrier to energy efficiency improvements (Forni and Zajáros 2014). Matschoss et al. (2013, p. 1486) note that, in the case of owneroccupied MoPs, lay people are ultimately responsible for a very large and complex technical system with a very long lifespan, and that the generally low rates of renovation in Europe, and the generally low level of energy improvement accomplished in renovations that are made, suggest that owners are not up to these responsibilities. Based on a literature review and expert interviews, Matschoss et al. (2013) give an overview of how decision making is structured in apartment buildings in nine European countries (Austria, Bulgaria, Czech Republic, Germany, Finland, France, Italy, Romania and Spain), with a more detailed discussion of three countries (Austria, Romania and Finland). Relying on earlier work by Uihlein and Eder (2009), they categorise the barriers identified as (1) genuine uncertainties as regarding cost-effectiveness, (2) financial barriers, (3) organisational problems, (4) lack of information and skills, (5) transaction costs and (6) other barriers that may be context dependent, noting that the categories tend to overlap and reinforce each other (Matschoss et al. 2013, p. 1486). The LEAF (2016) project, an Intelligent Energy Europe project which aimed to refurbish 24 apartment blocks in six countries, explored the governance, ownership and management arrangements for energy efficiency retrofit in Austria, Germany, Hungary, France, the UK and Sweden. The reasons identified for apartment blocks having lower energy 
efficiency ratings compared with other kinds of buildings fell into four categories: technical issues (for example, hard to treat solid wall construction), agreement issues, financial issues and the behaviour of residents.

In research into the legal regulation of MoPs in England, Bright and Weatherall (2017) suggest that there is a meta-category of governance barriers - those relating to the way in which MoPs are owned and managed - which both represent and shape the content of the various barriers referred to in the Matschoss and LEAF studies. Further, Lujanen (2010) identifies that the regulation of co-owned apartment blocks involves the collision of two types of law-the laws of association and property law-in ways that can cause conflict and difficulty. ${ }^{4}$ These laws set up organisational structures that regulate whether (and how) owners constitute themselves as a decision-making body and whether they can readily collaborate to install and finance energy upgrades in communal parts, and also in individual apartments, without the risk of works being impeded by the objections of a single or a small minority of apartment owners. The rules of ownership also prescribe how the building and apartments are owned-for example, whether parts such as the roof, foundations and windows are common parts or individually ownedand who, if anyone, has the power to carry out energy upgrades. Property law also determines financial issues about cost sharing between co-owners and whether owners can collaborate on funding upgrades. It is also property law that can create (or avoid) informational issues about who actually has the right to carry out such work to which parts of the building. Sitting alongside these governance arrangements will be regulatory measures about obtaining information about the energy efficiency of the building and potential for energy efficiency upgrades. Law, therefore, creates a unique set of barriers in relation to retrofit of MoPs, the detail of which requires to be augmented.

\section{Methodology}

This paper begins the process of 'colouring in' the outline provided by Matschoss et al. (2013), LEAF

\footnotetext{
${ }^{4} \mathrm{He}$ gives the example of Russia and Lithuania where courts have upheld apartment owners' rights not to join owners' associations: rulings which protect the important principle of freedom of association, but which may not be helpful to good management and upkeep of the buildings concerned.
}

(2016) and Bright and Weatherall (2017), by providing an in-depth delineation of the governance barriers to energy upgrades presented by the law of ownership and management in two European jurisdictions: England and Scotland. In order to ascertain the relevant law, a doctrinal analysis has been employed. Doctrinal analysis can be described as a two-stage process in which the researcher must first locate the relevant sources of law (in this case, a combination of legislation, precedent contained within case law and convention arising from the common law of each jurisdiction), then synthesise the material (in this case using a combination of deductive logic following on the legislation and inductive reasoning building up from case law and convention) to produce a definitive statement of the legal rules applicable in this area (Hutchinson and Duncan 2012, p. 111). The doctrinal approach is supplemented by the co-authors' expert knowledge of documentation and models typically used in MoPs. A theoretical analysis is then undertaken, which involves a review of literature relevant to a potential conceptual underpinning of the law in question followed by advancing a new normative framework that might justify reform of the current legal rules (Hutchinson and Duncan 2012, p. 104). Contemporary property thought focuses upon the rights of the individual, but in order to make energy upgrades in blocks of flats it is necessary to recognise that living in or owning a block of flats requires - at some level - a commitment to collective living with some of the sharing of costs and benefits. In many respects this is a particular contextual manifestation of a broader question that needs to be asked, to do with how property rights generally might be affected by the society-wide need to take action on climate change.

Despite both countries being part of the United Kingdom, England and Scotland have very different property law regimes. The English model is unique within Europe and uses the sale of (very) long leases for apartments, continuing the feudal ideas of landholding (medieval in origin), whereas the Scottish model provides for ownership of individual units and bears closer resemblance to many other systems found within Europe. MoPs also play a different role in the two countries' housing supply: in England only 21\% of homes are apartments, one of the lowest proportions in Europe (DCLG 2015). In Scotland, 38\% of homes are apartments - much closer to the European average (Scottish Government 2015). In both jurisdictions, there is a distinct lack of data on the prevalence of the differing 
management and ownership arrangements possible for apartment blocks. Our accounts of 'typical' arrangements should therefore be understood as based on the co-authors' professional expertise, pending the gathering of better empirical data. In England, the terms 'flat' and 'block of flats' are used to refer to individual units within the MoP and the MoP building respectively. In Scotland, the terms used are 'flat' and 'tenement'.

\section{Governance arrangements in England}

\section{Ownership}

Twenty-one percent of homes in England are selfcontained flats (DCLG 2015). Around half of those are flats which are in the ownership of private individuals, rather than social housing providers (councils or registered not-for-profit housing providers) (Future Climate/ TLT/Oxford University 2015).

Unlike civilian law systems prevalent in the rest of Europe, England has no concept of 'absolute ownership' of land. Instead what can be owned is known as an 'estate', that is 'land for a time'. These estates are divided into 'freeholds' (land that is held for effectively indefinite or perpetual time) and 'leaseholds' (land held for a definite or certain time period). A block of flats will have a freehold owner who owns the whole building, including the 'common' (or 'shared') parts, and the individual flats will be sold by the freeholder to leaseholders. ${ }^{5}$ Typical leases are for 99,125 or 999 years; if the flat is later sold the leaseholder transfers the lease to the new owner but the lease itself is not revised. Leaseholders may be owner-occupiers or may rent the flat out. The freehold of a block of flats is very often owned by a private individual or company who is not resident in the building, but simply collects a 'ground rent' from the leaseholders. The ground rent is usually small, and the value of the freehold of a whole building is nearly always much less than the collective value of the leases. However, the freehold of the block is not always privately owned: it may be owned by a social landlord (local authority or non-profit housing organisation) or jointly owned by the leaseholders.

\footnotetext{
${ }^{5}$ In 2002, a new legal system for flat ownership was introduced in England and Wales, called commonhold, which resembles condominium systems. But commonhold has not caught on, and anyway would only apply to new flats as they are built, where the retrofit challenge is at its least acute.
}

Management arrangements

The document at the heart of the English system is the lease which — as well as constituting the property right in itself - is a detailed contract between the freeholder and the leaseholder, determining the rights and responsibilities of both parties. There is, however, no such thing as a 'standard lease', and they are usually long, complex, often badly drafted and not in plain English. Notwithstanding the absence of standardisation, there are general patterns of how responsibilities are divided between the freeholder and leaseholder. Thus, the lease will almost always state that the leaseholder has responsibility for the maintenance of the interior of the flat and will usually limit what changes the leaseholder can make to the flat, and that the freeholder has the responsibility for the repair and maintenance of the common parts.

Within this broad pattern there are, however, important details that will turn on the wording of the particular leases. Although the freeholder is responsible for repair and maintenance of the common parts, what constitutes the 'common parts' will depend on the specific wording. Typically, the common parts include the roof, the foundations, the structure (including exterior walls), entrance halls, stairs, lifts, service conduits and shared outside space. Responsibility for windows will depend on the lease wording: it may be that the window frames belong to the freeholder and the glass to the leaseholder or that the leaseholder has both. Thus, the definition of what constitutes the 'flat' as opposed to the common parts of the building depends on the particular wording of the lease.

The lease will provide for the freeholder to recover the costs of the upkeep of the common parts of the block from the leaseholders (the 'service charge') and will set out the basis upon which the costs are apportioned amongst leaseholders, but commonly it is based on a percentage related to the size of the flat. Leaseholders are able to challenge service charges before a Tribunal if they are not 'reasonably incurred' (Landlord and Tenant Act 1985 , s. 19), a test that takes account not only of whether it is reasonable to do the works but also whether the cost itself is reasonable, and this may require consideration to be given to the financial impact on the leaseholders. Further, if the costs are above a certain threshold, there is also a statutory consultation process that must be carried out before the works can commence (Landlord and Tenant Act 1985, s. 20). 
Day-to-day management of the block and collection of the service charge on behalf of freeholders may be undertaken personally or through a managing agent. An association of leaseholders can apply to be officially recognised (known as a recognised tenants' association (RTA)) and is then entitled to information about the management and has some consultation rights. The RTA drafts its own constitution, which will cover issues such as meetings and voting. Service charges are a frequent source of dispute between freeholders and leaseholders and there are various routes by which leaseholders can take over more control of their building from freeholders. Where the leaseholders in a block collectively wish to do so they can nominate a purchaser to buy the freehold (which is normally done through a jointly owned company, but need not be) (Leasehold Reform, Housing and Urban Development Act 1993) or they can exercise the 'Right to Manage' (RTM) whereby they take over the responsibility for the upkeep of the building from the freeholder (but not the ownership) (Commonhold and Leasehold Reform Act 2002). The form of a RTM company is prescribed by statute and provides that the directors are responsible for the business of the company but there are no requirements to hold members' meetings. Where the leaseholders collectively own the building, the meeting and voting requirements (if any) will be set out in the relevant documents (usually the company's Articles of Association).

Governance arrangements in England and energy efficiency

The central, distinctive, feature of the English system is the freeholder/leaseholder relationship. A typical lease obliges the freeholder to 'repair and maintain' the building, but this does not cover improvements, so unless the lease expressly (and unusually) refers to improvements it is not possible for the freeholder (or management company) to recover the cost of any energy efficiency upgrades to the common parts. The distinction between what is a 'repair' and what is an 'improvement' is therefore a critical issue, but it is far from straightforward: as Lewison LJ recently observed, 'there is no bright line difference' between the two. 'Repair' does not include 'improvement' or even fixing 'design faults' unless this is necessary in order to conduct the repair (for

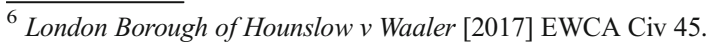

example, if the windows need replacing because they are rotten, and building regulations require replacement of single glazing with double glazed units). ${ }^{7}$ The installation of something new, such as wall insulation or solar panels where previously there were none, will, however, clearly amount to improvement.

The inability to recover the cost of improvements will be the norm whether the freehold is owned by an independent person or by the leaseholders collectively and it is this non-existence of any mechanism for carrying out improvements and recovery of improvement costs through the lease that makes it extremely unlikely that energy upgrades will be implemented. In practice, this means that the only way in which energy upgrades in communal areas can proceed is by the freeholder and leaseholders agreeing unanimously - and separately from the terms of their lease - that they want improvement works to proceed, and how they will share the costs.

Further, a typical private freeholder does not live in the building and therefore has no financial reason to make energy upgrades: the freehold value is unlikely to increase much (if at all) and the 'ground rent' will not change. Thus, despite having control of common areas, freeholders generally have no financial incentive to carry out works. The only exception will be a freeholder who has some other motivation. This might be the case, for example, where the building is owned by a social housing provider who has a concern to improve the condition of its rented housing, perhaps in order to help to alleviate fuel poverty and improve comfort for its tenants. Even then there will be difficulties with MoPs. This is because many council-owned blocks will contain a mix of both renters and leaseholders. This tenure mix comes about because some of the flats that were initially rented to tenants have been sold on long leases under the right to buy (RTB) - a statutory right to purchase their rented council home that was given to large numbers of council tenants in 1980 (and recently reinvigorated), and that has been exercised by nearly two million tenants (DCLG 2016). As with other leases, many of these RTB leases do not give the landlord power to make improvements and recover the costs. Some social landlords, however, have amended their standard RTB leases in recent years to allow for improvements to be carried out and the costs recovered through the service charge (although it is unclear what motivated these changes).

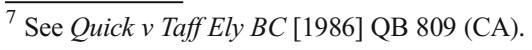


Although there is no data on the proportion of RTB leases that allow this, this means that it is sometimes permissible, according to the lease wording, to carry out improvements to the block of flats. The consequence of the tenure mix is that when a council wants to refurbish a block of flats it will have to ensure that the leaseholders are 'on-board' with the plans as the leaseholders may object either to the works themselves (perhaps, because the work will be disruptive and arguably a 'trespass') or to the costs (which the leaseholders can challenge under the statutory process discussed above at 'Management arrangements'). The difficulties that can arise are illustrated in a case study of the deep retrofit of five tower blocks in Oxford that is underway. The blocks are owned by the local authority and occupied by a mix of council rental tenants, leaseholders who have bought under the RTB and private rental tenants who are renting from leaseholders who have bought from the original RTB purchasers. The local authority is carrying out a major refurbishment of these blocks, which includes significant energy efficiency upgrades, but the substantial service charge bills (in the region of $€ 55,000$ per unit) have led to opposition from some leaseholders, and protracted litigation before a Tribunal (Bright et al. 2017).

Governance arrangements can also make energy efficiency upgrades difficult within individual flats. Leases are not straightforward documents, and leaseholders may be confused about their responsibility for different building elements. In addition, leaseholders are usually prohibited from making structural alterations within their flat (and there is no clear guidance on what is a structural alteration), although internal nonstructural alterations can generally be made. One practical illustration of the difficulties that might arise applies to condensing boilers. Since 2005, it has been a requirement in most domestic situations to install a highefficiency condensing boiler when replacing central heating boilers (HM Government 2016 s. 4.26 and HM Government 2013 p. 10), and this will require venting through an external wall. However, the external wall is almost always within the definition of "common parts' and therefore will belong to the freeholder so that any work done to the external wall will involve a 'trespass'.

In management arrangements where leaseholders have more control-where they jointly own the freehold, or exercise the right to manage - energy efficiency might be more likely to happen: certainly there are more opportunities for formal decision-making structures to be put in place which would allow for consideration of the issues, and it may mean that more decisions can be taken by majority. But there is no data to demonstrate this, and none of these arrangements can change lease wordings. This leaves the problem that it is usually not possible to make energy upgrades in communal areas and share costs without unanimous agreement including all leaseholders and the freeholder or to make significant alterations within individual flats.

\section{Governance arrangements in Scotland}

\section{Ownership}

Ownership of flats in Scotland is less complex than in England. In Scotland, there is no leasehold form of tenure. The owner of a flat will have the equivalent of the English freehold, which is referred to simply as 'ownership'.

The law governing flats is contained partly within the common law and partly in the Tenements (Scotland) Act 2004. In combination, these set out default rules of ownership of the various parts of a tenement. Each individual flat, including its exterior walls, is owned by the flat owner. A ground floor owner also owns the foundations beneath his flat. If there are two or more ground floor flats, each will own the section of the foundations immediately below their individual flat. A top floor flat owner also owns the roof above his flat. Again, if there is more than one top floor flat, each will own the section above it.

The tenement will also have 'common parts'. These include the main entry door from the street and the stairwell or lift, and in almost all buildings will also include shared pipes, gutters, chimney stacks and other structural features. Also included within the common parts are the section of the foundations below the stairwell and the section of roof above it. The owner of each flat in the block will also own a share of the common parts. In other words, if there are six flats in the tenement, each owner will have a one sixth share in the common parts. This share in the common parts is held in a form of tenure known as common ownership, which allows every owner to make non-exclusive use of the common parts.

It is important to note that these rules are only a default. It is possible — and quite common - for the title 
deeds to flats to vary these default rules. A fairly frequent variation is for the roof to be owned in common by all the individual flat owners rather than solely by the owner of the top flat, for example. There is no standard form which such variations will take and no empirical evidence on the types or frequency of such variations.

\section{Management arrangements}

Decisions relating to repair, maintenance and improvement of the different parts of a tenement are governed by three different sets of default rules. Which rules apply depends on the part of the tenement in question.

First, decisions in relation to the management of strategic parts of the building are governed by the Tenement Management Scheme, as set out in the 2004 Act. The Act defines the strategic parts (referred to as 'scheme property') to include (a) the roof, the foundations, external walls and any internal load bearing walls and (b) any part of the building which is in common ownership of the flat owners.

The Act provides that decisions in relation to the maintenance of strategic parts of the building must be taken by all owners of flats in the building, and must also be paid for by all owners of flats in the building, regardless of who actually owns the strategic part in question. In other words, although A owns the top flat and the roof, A is not free to keep (or neglect) the roof as he sees fit. Instead, the right to decide on maintenance of the roof is shared amongst all flat owners in the building. That cost is also shared by all owners in the building.

Such decisions are taken by way of a majority vote. All flat owners must be consulted. Each owner is entitled to one vote per flat owned. If a simple majority of votes is in favour of maintenance to a strategic part of the building, the work can go ahead. The cost of the work is split amongst flat owners - usually one share of the cost per flat owned, unless flats vary significantly in size - regardless of whether the owner votes in favour of the work or not.

Not every decision in respect of a strategic part of the building can be taken using this process. The Act contains a definition of 'scheme decisions' - the types of decisions which are to be regulated by the Scheme. Essentially, scheme decisions cover maintenance and repair of the strategic parts. Where what is sought is an improvement, such as the installation of solar panels or a new heating system, the Scheme has no application. For clarity's sake, these types of improvement decisions are referred to in this paper as 'non-scheme decisions'.

Second, decisions in relation to the management of individual flats, or non-scheme decisions in relation to any strategic part of the tenement which is in the ownership of a single owner, are taken by that owner alone.

Third, non-scheme decisions in relation to parts of the tenement which are in common ownership must be taken according to the common law rules. These require unanimity amongst all the owners before work can go ahead. Should one owner object, or simply remain silent, work cannot proceed.

Once again, it is important to note that these rules simply provide a default. It is common for the title deeds of flats to contain express rules as to how management decisions must be taken. These rules are usually created in a form of title condition known as a 'real burden': a positive or negative obligation on any owner of the flat, which is usually enforceable by the owner (at the time enforcement is sought) of any other flat in the tenement. It is commonly the case that all owners in the block will be subject to the same conditions, giving every owner rights against every other owner, whilst also binding him to the same conditions. Where such title conditions exist, the Tenement Management Scheme will not apply, and the other default rules may be varied. As with variations on the default ownership arrangements, there is no standard form which variations in relation to management arrangements will take and no empirical evidence on the types or frequency of such variations.

Where decisions about repair, maintenance or improvement can or must be taken by a group of owners (in other words, where they are scheme decisions, or non-scheme decisions relating to commonly owned parts of the building), there are no formal requirements governing the decision-making process. In some cases, an agent known as a factor will be engaged by the flat owners within a tenement. The precise powers and duties of the factor will be regulated by a contract between it and the flat owners, but commonly the factor will be obliged to carry out regular inspection of the building and empowered to carry out work to the building where costs are below a certain amount and to coordinate decision making where larger costs are entailed by works. In tenements where no factor is employed, owners must come to their own arrangements in managing the decision-making process. Again, there is no standard arrangement and no empirical evidence as to the types of arrangements in place. 
Governance arrangements in Scotland and energy efficiency

The law is complicated. A decision in relation to energy upgrade works may fall within any one of the three sets of default rules above or may not be dealt with by default rules at all if the title deeds contain conditions regulating the works. An owner is likely to have considerable difficulty ascertaining which set of rules is applicable in any particular case. As with English leases, Scottish title deeds can be unclear and difficult documents, which may (probably inadvertently) restrict opportunities for energy upgrades and/or leave owners in confusion about where responsibility lies for such works.

The default Tenement Management Scheme, in addition to having no application where contradictory title conditions are in place, is also restricted to decisions on repairs and maintenance of strategic parts. Energy upgrades are more likely to be considered 'improvements', meaning the Scheme has no application. This difficulty has been recognised to a certain extent by the Scottish Parliament who - uniquely in the UK-legislated to make energy upgrades easier for MoP owners, although only in a very limited way. The Climate Change (Scotland) Act 2009 amended the 2004 Act to specify that installation of insulation falls within the definition of maintenance. According to views expressed at an event held by LEAF in early 2016, this change has improved the rate of installation of insulation, at least by social housing providers. Although this change is welcome, its impact is obviously restricted, and there is no suggestion at present that other types of upgrade be brought within this definition.

The limited application of the TMS means that the majority of decisions on energy upgrades will require unanimous agreement of all owners in a tenement, which is obviously difficult to achieve for any number of reasons, including lack of finance, differing attitudes to the desirability of the work and difficulty in contacting non-resident owners, perhaps particularly those who have bought the flat as a rental property.

The ownership structure within tenements means that the problem above also exists where an energy upgrade which benefits an individual flat requires use to be made of a common part, usually for the installation of infrastructure relating to that upgrade. Unanimity is needed for that use to be made of the common part.

\section{How property law acts as a barrier to energy upgrades in MoPS}

In this section, we draw on the evidence above to identify a number of governance barriers to energy upgrades in MoPs arising directly from the way in which property law regulates ownership and management of flats. These barriers straddle the categories of financial barriers, agreement, organisational problems and lack of information and skills identified by Matschoss et al. (2013), LEAF (2016) and Bright and Weatherall (2017) and discussed above. In the following part, we develop the hypothesis that the underlying difficulty with property law in this context is its focus on the rights attaching to individual owners, rather than the responsibilities of the collective. Without further research, it is not possible to determine the precise extent to which these problems are replicated in the property law of other European jurisdictions, although on the basis of the authors' admittedly limited current knowledge, it seems likely that every country will be familiar with at least some of the barriers detected here.

\section{Misalignment of incentives arising from ownership rules}

The law of ownership in England results in a misalignment between the power (if any) to carry out energy upgrades and the principal benefits resulting from such works. The literature on energy policy refers to the 'split-incentive' problem as a commonly recognised issue within landlord-tenant relationships, defined by the UK Government as a situation where "the costs of energy efficiency improvements are borne by landlords, while the benefits (lower energy bills) accrue to current or future tenants' (DECC 2012, p. 18.) This disjuncture between landlord and tenant is played out in MoPs in extenuated form: in a rental situation the landlord can hope to benefit from any gain in the capital value of the improved building and may hope that over time rents will rise to reflect the benefit of living in a more energyefficient home, but in a MoP with flats sold as leaseholds, all the benefits are away from the freeholder. Even if the freeholder (landlord) has the right to improve common parts, it must generally bear the costs as the service charge cannot usually be used to reclaim money spent on improvement works, yet any increase in the value of the building flows generally to the leaseholders who 'own' the flats, and other benefits such as lower 
heating bills or warmer accommodation flow to the current occupiers of the flats, who may be the leaseholders or may be short term tenants renting from the leaseholders. Rather than any incentives being split, there is no incentive for the freeholder.

These issues could be resolved by the law ensuring that the power to carry out work, the responsibility for the cost of works and the benefit of completing the work all falls within the same hands. This would echo the default position in Scotland, in which flat owners have free rein within their own units, and each flat owner has a share of ownership in the common parts.

Routley et al. (2015) have made recommendations for reform to the English system, which would provide leaseholders with an independent right to make energy efficiency improvements to the common parts, and enable leaseholders to make alterations in their own flat provided that there is no harm to the building. If adopted, these recommendations would resolve the split incentives arising specifically from ownership law.

Regulation of management: no unitary body

Ownership law aligns the power to carry out upgrades to common parts with receipt of the benefits in the Scottish system, and in England in situations where the leaseholders jointly own the freehold or have the 'right to manage'. Despite this alignment of power with incentives, the law governing management of the decisionmaking process can mean barriers remain nevertheless.

Under the Scottish system, apartment owners are not required to organise themselves into a block management company or co-operative (or join a pre-existing one). The Tenements (Scotland) Act 2004, as a minimum requirement, stipulates only that flat owners should come together as and when needed to take action on repairs and upkeep, agreeing on a case-by-case basis who will undertake the management of the repair and maintenance works. In England, there may be a company structure if the leaseholders jointly own the freehold, or have the RTM, but it is not unusual for there to be no organised co-ownership decision-making body. The absence of any necessary, formalised corporate structure prevents flat owners jointly accessing loans or grants to pay for energy upgrades.

English and Scottish arrangements here contrast sharply with arrangements in the other European countries. Lujanen (2010) suggests that most property law systems require the formation of owners' associations in each apartment block. For example, in France, under the copropriété ownership model, every apartment owner becomes a member of the syndicat, a collectively owned, private legal entity with the objectives of the upkeep of the building and the management of the common parts (Service-public.fr 2016).

The absence of a formalised association in England and Scotland also profoundly limits the ability of government to regulate processes that would promote energy upgrades. For example, in Germany the owners' association is required to maintain a renovation fund of $1 \%$ of the value of the building, and in Finland the association is obliged to develop a maintenance and renovation plan.

Regulation of management: decision-making processes

Neither England nor Scotland has a necessary process to bring co-owners together for decision making. In England, as mentioned earlier, even where leaseholders do jointly own the freehold or have exercised the right to manage, there may be no requirement to hold regular (or any) co-owner meetings. In Scotland, general meetings are not part of the tenement management scheme. In other systems, where there are mandatory requirements for owners' associations, there are also mandatory arrangements for decision-making processes. For example, in Hungary, an annual meeting is required for apartment owners, as is the appointment of an 'audit committee', usually of three apartment owners. Such institutional arrangements are not all that is required: in France, there is a requirement for an annual residents' association meeting (although LEAF (2016) highlights that as it only has to meet once a year, it is not fully effective as a forum to drive action on energy efficiency).

Regulation of management: voting thresholds for decision making

In the English system, the freeholder may be in a very powerful position to undertake energy upgradeswhere leases allow it —without the specific agreement of the apartment owners (though leaseholders must be consulted for any significant expenditure). But, of course, there is little or no incentive for it to do so.

In Scotland, as in other European jurisdictions for which we have information, different majorities are required for co-owners to take different upkeep and 
improvement decisions. Scotland effectively requires unanimity for energy (and other) improvements, with the exception of insulation upgrades which can be undertaken on the same basis as repairs with a simple majority of apartment owners. In France, the Loi de transition énergétique of 2015 modified the rules to allow decisions about energy efficiency upgrades to be taken not by an absolute majority of flat owners' shares (as in the case of other improvements), but by a majority decision amongst attendees at the general assembly (as for other repair and maintenance). This tackles one of the most profound barriers to energy efficiency decision making in apartment blocks - the need to reach and engage apartment owners who may have no interest or who are difficult to contact.

Informational barriers arising from legal complexity

Apartment owners in England and Scotland face an informational barrier in understanding the way their property is owned and managed, and therefore the potential for them to make energy upgrades. Leases (in England) and title deeds (in Scotland) are complex documents that are rarely read. The law itself is difficult to follow. It is likely that the division of rights and responsibilities are poorly understood, particularly for owners of apartments who do not have easy access to legal advice.

This barrier is compounded by the regulation of energy performance certificates in the two countries. Across Europe, the 2010 recast Energy Performance of Buildings Directive requires that Energy Performance Certificates (EPCs) have to be issued whenever a building or building unit is sold or rented out. There are separate systems for the management and regulation of EPCs in England and Wales, and in Scotland. Both systems use the same methodology and, in both countries, EPC assessments in apartment blocks are carried out on individual apartments, rather than on the whole building. This is a minority approach within Europe: $74 \%$ of members states issue EPCs for apartments based on an assessment of the whole apartment building (CAEED 2016). The merits of the two approaches, as they have been seen by policymakers across Europe, have been considered by the Concerted Action-EPBD:

The certification of an individual building unit (i.e. apartment) could provide tailor-made measurements for its refurbishment, especially when there is an individual heating system and the cost of the EPC is borne by the owner. However, it is difficult to provide suggestions for measurements concerning the whole building, e.g., roof insulation or replacement of a common boiler. The certification of the whole building, on the other hand, provides recommendations for the building envelope, and the heating system and its costs are divided amongst the owners ... It would be best to have a certificate for both the building as well as for the individual apartment, but this is considered to be too expensive. (CA-EED 2016, p. 18).

This means that, in England, the freeholder (or employed managing agent) has no information about energy efficiency: the principal 'owner' of the building is completely missed by this aspect of the Energy Performance of Buildings regulations. In Scotland, individual flat owners will have their own EPC, but no information on the whole building for which they are also jointly responsible. In neither country is any information provided about energy efficiency in common parts (e.g. for communal lighting or lifts).

There is also a lack of specific information about the potential for energy efficiency upgrades across apartment blocks as EPCs only provide information on individual apartments. An obvious policy development would be to introduce a requirement for EPCs to be issued on apartment blocks as whole buildings, as well as on individual apartments. This would parallel the situation in France where there is a mandatory energy performance diagnosis and audit in co-ownership properties with a common heating system (LEAF 2016).

\section{Reconceptualising property law in MoPS to minimise governance barriers}

The preceding section has enumerated specific instances in which the current rules of property law in England or Scotland (or both) act as a barrier to energy upgrades in MoPs. Individual solutions can obviously be devised for each of these problems. Our contention, however, is that a piecemeal approach of this kind will be ineffective, because the solutions proposed will fit poorly with the understanding of property ownership which prevails in European jurisdictions. Reform will be more effective if it proceeds from a fundamental reconceptualisation of ownership insofar as it relates to MoPs. 
Despite finding their roots in a variety of legal traditions, property law systems in Europe are largely united in a basic understanding of ownership as providing 'sole and despotic dominion...over the external things of the world, in total exclusion of the right of any other individual in the universe.' (Blackstone 1753, p. 1). Harris (1996, pp. 29-32) describes the owner as 'entirely free to do what he will with his own, whether by way of use, abuse or transfer' and puts 'self-seekingness' at the cornerstone of his notion of ownership. In reality, ownership is never truly unqualified, as Harris recognises when he acknowledges that 'property limitation' rules place limits on the way in which assets are used through criminal law, planning regulations, bankruptcy rules and so on. Nevertheless, the sense remains that ownership is a right in relation to which any restrictions must be justified, and the pivotal idea of 'self-seekingness' that Harris refers to is inimical to any idea that owners must be 'other-regarding'. From that perspective, ownership has come to be treated within the law as a sort of objective and neutral truth, the validity of which is never questioned, and the underlying values of which are rarely articulated, let alone challenged (Cowan et al. 2016, pp. 227-228).

In so far as MoPs are concerned, this outlook on ownership of parts of the building is reflected in the cry: 'My Apartment is my Castle: Leave me Alone!' (a chapter heading in van der Merwe 2015). In practice, this conceptualisation of ownership as an absolute right occasionally subject to restrictions is a poor fit for ownership of part of a MoP. An owner of an apartment is in a fundamentally interdependent relationship with every other owner in the building: each relies on the other to provide structural support and shelter, and each must necessarily share certain parts of the building such as the front door if any of them is to be able to exercise their rights of ownership. The individualistic view of ownership which has so much traction within the various European legal traditions makes little sense here.

In addition, our contention is that this individualistic approach to property ownership underlies most of the governance barriers outlined in 'How property law acts as a barrier to energy upgrades in MoPS' above. Calculating the outcome of a communal energy efficiency measure as a series of individual profits and losses results in the idea that benefits are misaligned, rather than enjoyed by the broader MoP community as a whole. The need for communal management fits poorly within a system where each owner is viewed as an individual. This notion is reflected within the study by
Matschoss et al. (2013, p. 1491), in which the country report on Austria noted the comment of an expert that the 'owners do not really feel responsible for the condominium and almost nobody is aware that the owner association commonly owns the whole building together. This makes it difficult to raise awareness for renovation measures'. What is more, potential legal responses addressing these barriers are hard to justify where this paradigm prevails. Rules which tackle the misalignment of benefits by obliging an owner to take an action which may benefit her less than her neighbours, or may not benefit her at all, appear illegitimate and illogical. Requirements to participate in communal decision making, or to accept the decisions of a majority, appear unfairly burdensome. In general, the imposition of obligations presents itself as a series of piecemeal limitations on the default freedom of owners, which increases legal complexity, reinforcing existing informational barriers.

Our proposal is to rethink the idea of ownership in relation to MoPs to focus on its communal nature. We draw here on the work of the progressive property group of theorists (Alexander et al. 2009). Progressive property scholars assert that property rights exist to serve a number of underlying values, and argue that principal amongst these values should be the promotion of 'human flourishing' - simply put, the ability to live a good life. To contribute to human flourishing, any system of property law must certainly allow for secure rights to be held in land and other assets, since a secure home, for example, is necessary for a good life. However, to meaningfully contribute to a good life, property law must also recognise that owners of assets have obligations to others in society (Alexander 2009). The nature of these obligations may incorporate environmental concerns (Alexander 2009, pp. 796-801), the need to 'acknowledg[e] and balanc[e] interests in the aggregate welfare or wealth of society', and the desirability of protecting the poor and future generations (Peñalver 2009, pp. 868-869). Progressive property scholars also emphasise that property law itself is not a set of unchanging entitlements, but rather is a living institution that can and should be drawn and redrawn in response to the changing needs of society. In order to meet the retrofit challenge, our contention is that models of property ownership employed in relation to MoPs should be redrawn in precisely this way in order to move away from individualism, and encompass instead collectivefocused ideas about governance of the commons and the welfare of society. 
If we view the law of property in relation to MoPs through this lens, an argument can be made for an understanding of ownership that incorporates the interdependence inherent in the structure of the apartment building. At a basic level, owners of any part of the building should be under an obligation to take into account the needs of other owners, and to make decisions about their occupation and use of the property in a way that is reasonable bearing that obligation in mind. Blandy and Robinson (2001, pp. 408) acknowledge 'the inevitable difficulties and co-dependency which arise from sharing the same building' and suggest, citing the work of Bailey and Robertson, that the 'idea that residents have to give up 'some of their individual rights ... but gain collective rights ... of control over the immediate environment surrounding their home' requires embedding in our conception of multi-occupancy'. This co-dependency and co-operation can be most easily accommodated within progressive understandings of property. Within this conceptualisation, the responsibility to (for example) attend meetings with other owners to decide on works that would benefit the $\mathrm{MoP}$ as a whole follows logically from the choice to acquire the ownership interest in the first place. A collectivist understanding of ownership would be a sound basis on which to resolve the issues around misalignment of incentives and regulation of management outlined above. It may also create scope for imposing penalties on owners who do not fulfil the responsibilities attaching to their ownership or justify incentives for groups of owners to embrace collectivism in order to achieve retrofit goals. In addition, a reconceptualisation of this kind would go a long way towards making the law more coherent, thereby reducing the informational barriers.

In arguing for a reconceptualisation of ownership in relation to MoPs, we do not mean to suggest that current property law rules within European systems uniformly fail to recognise obligations on apartment owners. As we have indicated above, such obligations can and do exist. However, our contention is that a more fundamental shift in the predominant paradigm of ownership will be needed to effect the systematic changes in MoP governance regimes which are likely to be necessary to meet European energy efficiency targets.

\section{Conclusions and further research}

Article 19 of the EED requires member states to "evaluate and if necessary take appropriate measures to remove regulatory and non-regulatory barriers to energy efficiency', including as regards 'the split of incentives... ... among owners [of a building].' The doctrinal analysis above demonstrates that property law rules create a particular set of governance barriers situated within the broader model identified in the energy efficiency literature to date. The law regulating ownership of different parts of a MoP creates a misalignment of incentives for retrofit works, where the power to carry out the works, the responsibility to bear the costs and the benefits received as a result are not all held in the same hands. The legal rules (or absence of rules) around decision-making processes create organisational barriers and impinge on the capacity of MoP owners to obtain funding for works or benefit from cost-sharing arrangements. The complexity of the law generates informational barriers, particularly for MoP owners without easy access to legal advice. Underpinning these specific issues, as explored in our theoretical inquiry above, is an embedded sense of ownership as an individual right. MoP owners are fundamentally interdependent. Reconceptualising the law of MoP ownership within the collectivist understanding set out by progressive property scholarship could provide a solid theoretical base for tackling the governance barriers created by property law in a holistic fashion, rather than through piecemeal legal reform.

The analysis presented above makes clear that it will be important for Europe, collectively and as individual states, to obtain a comprehensive documentation of the law around ownership and management arrangements in MoPs. Property law rules are as important as the physical features of buildings in determining the energy efficiency retrofit opportunities. To some extent, the gathering of cross-European insight in this area may have been neglected due to the specialist nature of the legal issues and the huge variation in property law between and even within member states, as shown by England and Scotland. However, the significance of the property law barrier to energy efficiency suggests that these challenges must now be faced.

Empirical work will also be essential in understanding the extent of the barriers here. Ownership and management of individual buildings will, in many EU countries, be determined to some extent by the specific agreements between owners. Research is needed into those agreements - title deeds, leases, contracts with building managers etc. - and how management is delivered in practice. More also needs to be understood about 
decision-making behaviours for energy efficiency within prevailing governance arrangements. How are discussions about energy efficiency conducted within residents' groups or meetings? How do professional building managers interact with non-professional home owners? Qualitative and quantitative research focused on group decisions in apartment blocks to date seems absent.

The data provided by further research will allow for the reconceptualisation hypothesis outlined above to be fully tested. Ultimately, this may form the basis of proposals for law reform designed to tackle the barriers to retrofit created by property law throughout Europe.

The law is complex, and making the changes necessary to address the decision-making barriers to energy efficiency is challenging, but reform is possible and can be achieved without - as Article 19 says - 'prejudice to the basic principles of the property and tenancy law of the Member State.' Regulation of Europe's apartment blocks will reflect the strength of society's view that there is a real need to tackle the causes and effects of climate change.

\section{Compliance with ethical standards}

Conflict of interest The authors declare that they have no conflicts of interest.

Open Access This article is distributed under the terms of the Creative Commons Attribution 4.0 International License (http:// creativecommons.org/licenses/by/4.0/), which permits unrestricted use, distribution, and reproduction in any medium, provided you give appropriate credit to the original author(s) and the source, provide a link to the Creative Commons license, and indicate if changes were made.

\section{References}

Alexander, G. S. (2009). The social-obligation norm in American property law. Cornell Law Review, 94, 745-819.

Alexander, G. S., Peñalver, E. M., Singer, J. W., \& Underkuffler, L. S. (2009). A statement of progressive property. Cornell Law Review, 94, 743-744.

Blackstone, W. (1753). Commentaries on the Laws of England (1765-1769), vol 2.

Blandy, S., \& Robinson, D. (2001). Reforming leasehold: discursive events and outcomes, 1984-2000. Journal of Law and Society, $28,384$.

Bright, S. and Weatherall, D. (2017). Mapping the governance barriers to energy efficiency in flats. Journal of Environmental Law, 29, 203-229.
Bright, S., Weatherall, D., and Willis, R (2017). A case study of deep retrofit in mixed tenure (rented and owned) UK social apartment blocks. Proceedings of the eceee 2017 Summer Study (forthcoming)

CA-EED (2016). Implementing the energy performance of buildings directive. [online] Lisbon: ADENE, p. 18. Available at: http://www.epbd-ca.eu.

Cowan, D., Fox O'Mahony, L., \& Cobb, N. (2016). Great debates in land law. Chippenham and Eastbourne: Palgrave MacMillan.

DCLG. (2015). English housing survey headline report 2013-14, [online] (p. 44). London: Department for Communities and Local Government Available at: https://www.gov.uk/dclg.

DCLG. (2016). Thousands more people taking up their right to buy [online]. London: Department for Communities and Local Government Available at: https://www.gov. uk/government/news/thousands-more-people-taking-uptheir-right-to-buy.

DECC, (2012). The energy efficiency strategy: the energy efficiency opportunity in the UK. Available at: https://www.gov. uk/government/uploads/system/uploads/attachment data/file/65602/6927-energy-efficiency-strategy-the-energyefficiency.pdf.

Eurostat (2015) Housing conditions in 2014: 7 persons out of 10 in the EU live in a dwelling they own [online] Available at: http://tinyurl.com/ntgkhuz.

Forni, T. \& Zajáros A., (2014) Split incentives, executive summary WG 5.4 [online] Concerted Action EED, p. 1. Available at: http://www.ca-eed.eu/.

Future Climate/TLT/Oxford University, (2015).Future-proofing flats: overcoming legal barriers to energy improvements in private flats, Workshop report. [online]. Available at: futureclimate.org.uk/.

Harris, J. W. (1996). Property and justice. Oxford: Oxford University Press.

Hirst, E., \& Brown, M. (1990). Closing the efficiency gap: barriers to the efficient use of energy. Resources, Conservation and Recycling, 3(4), 267-281.

HM Government (2013) Domestic Building Services Compliance Guide (2013 Edition) [online] Available at: https://www.gov. uk/government/uploads/system/uploads/attachment_ data/file/453968/domestic_building_services_compliance guide.pdf.

HM Government (2016) Approved Document L1B: conservation of fuel and power in existing dwellings, 2010 edition (incorporating 2010, 2011, 2013 and 2016 amendments) [online] Available at: https:/www.gov.uk/government/publications/conservationof-fuel-and-power-approved-document-l.

Hutchinson, T., \& Duncan, N. (2012). Defining and describing what we do: doctrinal legal research. Deakin Law Review, 17(1), 83-119.

Jaffe, A. B., \& Stavins, R. N. (1994). The energy-efficiency gap: what does it mean? Energy Policy, 22(10), 804-810.

Janda, K.B., Wilson, C., Bartiaux, F. and Moezzi, M. (2015) Improving efficiency in buildings: conventional and alternative approaches. Chapter 9. In: Ekins, P., Bradshaw, M. and Watson, J. (eds.) Global energy: issues, potentials and policy implications. Oxford University Press, Oxford, 163-188.

Low Energy Apartment Futures. (2016). Improving the energy efficiency of apartment blocks LEAF final report [online]. Edinburgh: LEAF Available at: www.lowenergyapartments.eu. 
Lujanen, M. (2010). Legal challenges in ensuring regular maintenance and repairs of owner-occupied apartment blocks. International Journal of Law in the Built Environment, 2, 178-197.

Lutzenhiser, L. (1993). Social and behavioural aspects of energy use. Annual Review of Energy and the Environment, 18, 247-289.

Matschoss, K., et al. (2013). Energy renovations of EU multifamily buildings: do current policies target the real problems? In: Rethink, renew, restart. Proceedings of the eceee 2013 Summer Study. Stockholm: Berg.

Peñalver, E. M. (2009). Land Virtues. Cornell Law Review, 94 , 821.

Routley, M., Bright, S., \& Weatherall, D. (2015). Briefing note for all-party round table meeting on leasehold issues. [online]. London: University of Oxford/TLT/Future Climate Available at: http://futureclimate.org.uk/.

Scottish Government. (2015). Scottish house condition survey: 2014 key findings, [online] (p. 15). Edinburgh: The Scottish Government.
Service-public.fr, (2016). Syndic de copropriété. [Online]. [Accessed 6 June 2016]. Available at: www.service-public. $\mathrm{fr} /$ particuliers/vosdroits/F2608.

Shove, E. (2010). Beyond the ABC: climate change policy and theories of social change. Environment and Planning A, 42(6), 1273-1285.

Sorrell, S. et al. (2000). Barriers to energy efficiency in public and private organisations. Available at: http://www.sussex.ac. uk/Units/spru/publications/reports/barriers/final.html.

Uihlein, A. and Eder, P. (2009). Towards additional policies to improve the environmental performance of buildings. European Commission Joint Research Centre, Institute for Prospective Technological Studies. JRC Environmental and Technical Reports EUR 23775 EN-2009.

Van der Merwe, C. (2015). European Condominium Law. Cambridge: Cambridge University Press.

Weber, L. (1997). Some reflections on barriers to the efficient use of energy. Energy Policy, 25(10), 833-835. 